\title{
PENGARUH KONSENTRASI PELARUT DAN LAMA EKSTRAKSI PADA PRODUKSI KARAGENAN
}

\author{
Marselino S. Gerung 1 , Roike I. Montolalu ${ }^{2}$, Helen J. Lohoo ${ }^{2}$, Verly Dotulong ${ }^{2}$, \\ Nurmeilita Taher ${ }^{2}$, Feny Mentang ${ }^{2}$, Grace Sanger ${ }^{2}$. \\ ${ }^{1}$ Mahasiswa pada Program Studi Teknologi Hasil Perikanan FPIK UNSRAT Manado. 95115. \\ ${ }^{2}$ Staf Pengajar pada Program Studi Teknologi Hasil Perikanan FPIK UNSRAT Manado. 95115. \\ E-mail: marselino_gerung@yahoo.com
}

\begin{abstract}
The purpose of this study is to obtain carrageenan from red seaweed Kappaphycus alvarezii using the steam method. In this study the treatment of $4 \% \mathrm{NaOH}$ and $5 \% \mathrm{KOH}$ was used and the extraction time was 7 hours and 10 hours. The stages of making carrageenan are; drying, soaking, washing, extraction, settling, filtering, drying and grinding. The results of this study showed that the highest yield was in $4 \% \mathrm{NaOH}$ treatment, 10 -hour extraction time was equal to $18.15 \%$. The lowest water content was obtained from $5 \% \mathrm{KOH}$ treatment, 10 extraction time which was $1.9 \%$. The best $\mathrm{pH}$ value is in $4 \% \mathrm{NaOH}$ treatment, 10 hours extraction time is 7.58 . The best results of gel strength were obtained from $5 \% \mathrm{KOH}$ treatment, 7 hours extraction time which was $78.3 \mathrm{~mm} / \mathrm{g} / \mathrm{sec}$.
\end{abstract}

Keyword: Carrageenan, Kappaphycus alvarezii, Steam Method, $\mathrm{NaOH}, \mathrm{KOH}$.

Penelitian ini bertujuan untuk mendapatkan karaginan dari rumput laut merah Kappaphycus alvarezii dengan menggunakan metode uap. Pada penelitian ini digunakan perlakuan konsentrasi $\mathrm{NaOH}$ 4\% dan $\mathrm{KOH} \mathrm{5 \%} \mathrm{dan} \mathrm{waktu} \mathrm{ekstraksi} 7$ jam dan 10 jam. Tahapan pembuatan karaginan ini adalah pengeringan, perendaman, pencucian, ekstraksi, pengendapan, penyaringan, pengeringan dan penggilingan. Hasil penelitian ini diperoleh rendemen terbanyak ada pada perlakuan $\mathrm{NaOH} 4 \%$, waktu ekstraksi 10 jam yaitu sebesar 18,15\%. Kadar air yang paling rendah diperoleh dari perlakuan KOH 5\%, waktu ekstraksi 10 yaitu sebesar $1,9 \%$. Nilai pH terbaik ada pada perlakuan $\mathrm{NaOH} 4 \%$, waktu ekstraksi 10 jam yaitu sebesar 7,58. Hasil penelitian kekuatan gel paling terbaik diperoleh dari perlakuan $\mathrm{KOH}$ $5 \%$, waktu ekstraksi 7 jam yaitu sebesar $78,3 \mathrm{~mm} / \mathrm{g} / \mathrm{det}$.

Kata kunci: Karaginan, Kappaphycus alvarezii, Metode Uap, $\mathrm{NaOH}, \mathrm{KOH}$.

\section{PENDAHULUAN}

\section{Latar Belakang}

Kebutuhan dunia terhadap karaginan terus mengalami peningkatan dengan bertambahnya penduduk di dunia terutama di Indonesia. Karena itu, sangat diperlukan adanya upaya serius untuk memacu produktivitas rumput laut merah Kappaphycus alvarezii sebagai sumber karaginan, baik secara kualitas maupun kuantitas.

Sejak dicanangkannya rumput laut dalam program revitalisasi, hingga saat ini pemerintah berupaya mengembangkan industri hilir rumput laut melalui pengembangan industri yang bernilai tambah yaitu alkali treated cottonii (ATC) dan refined carrageenan (RC). Upaya tersebut dalam rangka menambah devisa negara, dan memfasilitasi masyarakat yang umumnya hidup di wilayah pesisir dalam mengelola rumput laut menjadi karagenan.
Ekstraksi rumput laut menghasilkan dua jenis karaginan yaitu semi refined carrageenan (SRC) dan refined carrageenan (karaginan murni). Proses ekstraksi karaginan dari rumput laut dengan penambahan alkali dapat meningkatkan sifat-sifat mekanis gel karagenan (Campo et.al., 2009). Penelitian yang telah dilakukan (Panggabean et.al., 2018) ekstraksi karagianan rumput laut merah Kappaphycus alvarezii dengan perlakuan perendaman pelarut $\mathrm{KOH} 4 \%$ dan $\mathrm{NaOH} 3 \%$ mendapatkan rendemen menggunakan pelarut $\mathrm{NaOH}$ sebesar $10 \%$ dan $\mathrm{KOH}$ sebesar $14 \%$, kadar air dari pelarut $\mathrm{NaOH}$ sebesar 3,75\% dan $\mathrm{KOH}$ sebesar $5 \%$, dengan lama ekstraksi yaitu 5 jam dengan suhu $70^{\circ} \mathrm{C}$.

Proses produksi karaginan secara umum dilakukan dengan metode pengendapan dan perebusan dalam panci yang memakan banyak waktu dan tenaga selama proses pembuatan karagenan. Dalam rangka menunjang program pemerintah dalam pengembangan industrialisasi 
rumput laut di hilir, maka teknologi sederhana dalam memproduksi karaginan dengan metode uap dapat dijadikan acuan untuk diterapkan dan dikembangkan pada skala UKM (Usaha Kecil Menengah). Proses produksi karaginan dengan metode uap adalah metode yang sebelumnya sudah dilakukan oleh Panggabean et.al. (2018), proses ekstraksi rumput laut dengan metode uap sangat berbeda jauh dari metode yang lainnya dimana tidak terlalu banyak menghabiskan waktu dan tenaga selama proses pembuatan karagenan. Dengan diharapankannya metode uap ini dapat menghasilkan karaginan dengan kualitas yang dapat memenuhi standar yang telah dipersyaratkan oleh FAO.

\section{METODOLOGI PENELITIAN}

\section{Bahan dan alat}

Bahan baku penelitian ini adalah rumput laut jenis Kappaphycus alvarezii diperoleh dari Pulau Nain, Sulawesi Utara. Bahan penunjang penelitian yaitu $\mathrm{NaOH}$ yang didapatkan dari toko CV. Intraco Makassar, $\mathrm{KOH}$, dan $\mathrm{KCL}$ yang didapatkan dari PT. Nitra kimia Yogyakarta serta akuades yang didapatkan dari Apotek Gracia.

Alat-alat yang digunakan dalam penelitian ini adalah kompor, wadah dengan muatan $\pm 10 \mathrm{~L}$, timbangan digital 4 digit, gelas ukur $100 \mathrm{~mL}$, spatula, kertas lakmus, kain saring (blacu), Beaker glass $1000 \mathrm{~mL}$, gunting, kuali besar (belanga), mesin uap (dirancang oleh Panggabean et.al., 2018), saringan, aluminum foil.

\section{Metode Penelitian}

Analisa data yang digunakan dalam penelitian ini adalah metode Rancangan Acak Lengkap (RAL) Faktorial dengan dua Perlakuan yaitu:

Perlakuan konsentrasi (A) alkali yang terdiri atas dua taraf:

$\mathrm{A} 1=$ Konsentrasi $\mathrm{NaOH} 4 \%$

A2 $=$ Konsentrasi $\mathrm{KOH} \mathrm{5 \%}$

dua taraf:

Perlakuan lama ekstraksi (B) terdiri atas

$\mathrm{B} 1=7 \mathrm{jam}$

$\mathrm{B} 2=10 \mathrm{jam}$

\section{Tata Laksana Penelitian}

Tahapan penelitian ini adalah modifikasi penelitian yang telah dilakukan oleh Panggabean et.al. (2018). Berikut ini adalah diagram alir ekstraksi pembuatan karaginan:

\section{Persiapan bahan baku}

Bahan baku rumput laut kering Kappaphycus alvarezii yang diperoleh, dikeringkan sekitar 1-2 jam dengan sinar matahari sebelum diproses menjadi karagenan. Rumput laut kering kemudian dikebas-kebas sampai butiran-butiran material tidak menempel lagi. Rumput laut kemudian ditimbang menggunakan timbangan digital masing-masing $200 \mathrm{gr}$ x 4 wadah untuk kemudian direndam dengan larutan konsentrasi $\mathrm{NaOH} 4 \%$ dan $\mathrm{KOH}$ $5 \%$.

\section{Perendaman dengan $\mathrm{NaOH}$ dan $\mathrm{KOH}$}

Rumput laut dicuci dengan air biasa dan direndam selama 30 menit. Kemudian rumput laut masing-masing direndam dengan $\mathrm{NaOH}$ (4\%) dan $\mathrm{KOH}(5 \%)$ selama $12 \mathrm{jam}$. Adapun perbandingan massa rumput laut dengan $\mathrm{NaOH}$ maupun $\mathrm{KOH}$ adalah 1:20 ( gr/ml). Setelah 12 jam direndam, rumput laut dinetralkan dengan menggunakan air biasa hingga mencapai $\mathrm{pH} 7-$ 9. Kemudian rumput laut dipotong kecil-kecil ukuran $\pm 2 \mathrm{~cm}$.

\section{Ekstraksi karaginan dari rumput laut Kappaphycus alvarezii}

Karaginan dari rumput laut diekstraksi dengan menggunakan metode uap (kuali besar yang telah dimodifikasi menjadi mesin uap). Rumput laut yang sudah dipotong-potong dimasukan dalam wadah ekstraksi dengan perbandingan 1:20 kemudian dimasak atau ekstraksi dengan menggunakan metode uap/mesin uap yang dirancang sendiri pada suhu $65-75^{\circ} \mathrm{C}$ dengan waktu 7 dan 10 jam. Setelah itu, sampel disaring menggunakan kain saring kemudian dihasilkan filtrat. Filtrat ditampung dalam wadah lalu tambahkan $\mathrm{KCl}$ $(1,5 \% / 1000 \mathrm{ml}$ filtrat). Pengendapan dengan $\mathrm{KCl}$ dilakukan selama 15 menit, dan serat yang timbul disaring serta dicuci dengan menggunakan akuades. Sampel diletakkan dalam wadah pencetak untuk kemudian dikeringkan dalam oven dengan suhu $60-70^{\circ} \mathrm{C}$ kemudian ditimbang dan dihaluskan.

\section{Prosedur Analisa}

Analisa yang digunakan dalam penelitian ini adalah Rendemen (AOAC, 2005), Kadar Air (AOAC,1995), pH (AOAC, 2005), dan Kekuatan gel, (Distantina et.al., 2010). 


\section{HASIL DAN PEMBAHASAN}

\section{Rendemen}

Rendemen yang dimaksud dalam penelitian ini adalah berat karagenan yang terkandung dalam rumput laut kering dan dinyatakan dalam persen. Rendemen karaginan yang dihasilkan dalam penelitian ini berkisar 13,75-18,7\% dapat dilihat pada (Gambar 1).

Tabel 1. Hasil Analisa Rendemen Tepung Karagenan Rumput Laut Merah Kappaphycus alvarezii.

\begin{tabular}{ccccc}
\hline Kode & \multicolumn{2}{c}{ Ulangan $\%$} & $\begin{array}{c}\text { Rata-rata } \% \\
\text { Rendemen }\end{array}$ & $\begin{array}{c}\text { Standev } \\
\%\end{array}$ \\
\cline { 2 - 4 } sampel & 1 & 2 & 13,62 & 0,18 \\
A1B1 & 13,75 & 13,50 & 18,15 & 0,84 \\
A1B2 & 18,75 & 17,56 & 14,62 & 0,53 \\
A2B1 & 14,25 & 15,00 & 17,17 & 0,47 \\
A2B2 & 17,50 & 16,84 & &
\end{tabular}

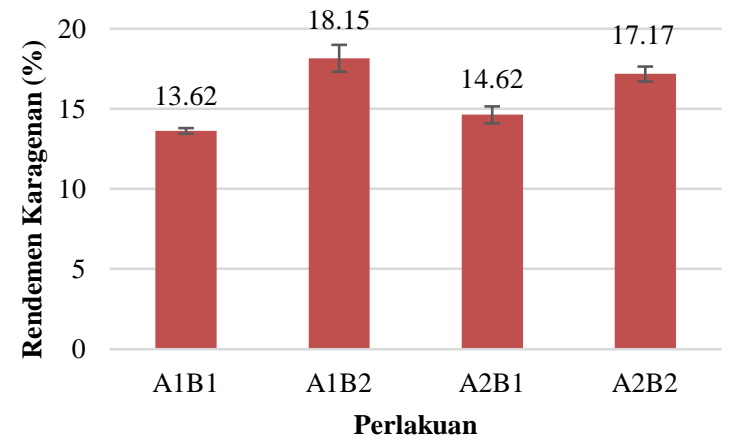

Gambar 1. Histogram Rendemen Tepung Karagenan Rumput Laut Merah Kappaphycus alvarezii.

Ket. A1B1 ( $\mathrm{NaOH} 4 \%$, waktu ekstraksi 7 jam)

A1B2 ( NaOH 4\%, waktu ekstraksi10 jam)

A2B1 (KOH 5\%, waktu ekstraksi 7 jam)

A2B2 (KOH 5\%, waktu ekstraksi10 jam)

Berdasarkan hasil analisa rataan rendemen karagenan dengan metode uap dapat dilihat pada (Tabel 1) menunjukkan bahwa nilai rendemen tertinggi terdapat pada perlakuan A1B2 $(\mathrm{NaOH} 4 \%$, waktu ekstraksi 10 jam) sebesar $18,15 \%$ dan nilai rendemen terendah yaitu $13,62 \%$ dari perlakuan A1B1 $(\mathrm{NaOH} 4 \%$, waktu ekstraksi 7 jam). Dari hasil penelitian yang dilakukan oleh (Panggabean et.al., 2018) menunjukkan rendemen ekstraksi karaginan dari pelarut $\mathrm{KOH} 4 \%$ dan $\mathrm{NaOH} 3 \%$ masingmasing $14 \%$ dan $10 \%$ dengan waktu ekstraksi yaitu 5 jam, penelitian yang dilakukan oleh Ega (2015), menunjukkan bahwa rendemen yang diperoleh dengan metode endapan pada waktu ekstraksi 19 jam yaitu sebanyak 46,39\%, sedangkan pada waktu ekstraksi 16 jam rendemen yang diperoleh yaitu $40,14 \%$, sedangkan penelitian yang dilakukan oleh Ningshi (2014), rendemen yang dihasilkan dari penggunaan konsentrasi $\mathrm{NaOH} 8 \%$ dan konsentrasi $\mathrm{NaOH} 4 \%$ berkisar antara 37,368,67\% dengan waktu ekstraksi 19 jam.

Rendemen karaginan mengalami peningkatan pada setiap penambahan waktu ekstraksi pada konsentrasi perlakuan pelarut $\mathrm{NaOH}$ ataupun $\mathrm{KOH}$ (Gambar 1). Menurut Hudha et.al., (2012) pelarut alkali sangat diperlukan dalam proses ekstraksi rumput laut menjadi karaginan, karena pelarut alkali dapat meningkatkan daya larut karaginan dalam air dan mencegah terjadinya reaksi hidrolisis ikatan glikosidik pada molekul karaginan.

\section{Kadar Air}

Kadar air merupakan jumlah air dan bahan volatile dalam karagenan. Kadar air tepung karagenan yang dihasilkan pada penelitian ini berkisar antara 1,90-3,06\%. Kadar air terendah diperoleh dari A2B2 $(\mathrm{KOH}$ $5 \%$, waktu ekstraksi 10 jam) sebesar 1,90 dan nilai rata-rata tertinggi dari perlakuan A2B1 (KOH 5\%, waktu ekstraksi 7 jam) data selengkapnya dapat dilihat pada Tabel 2. Kadar air hasil penelitian ini berada dalam standar karagenan yang ditetapkan oleh FAO yaitu maksimum sebesar $12 \%$.

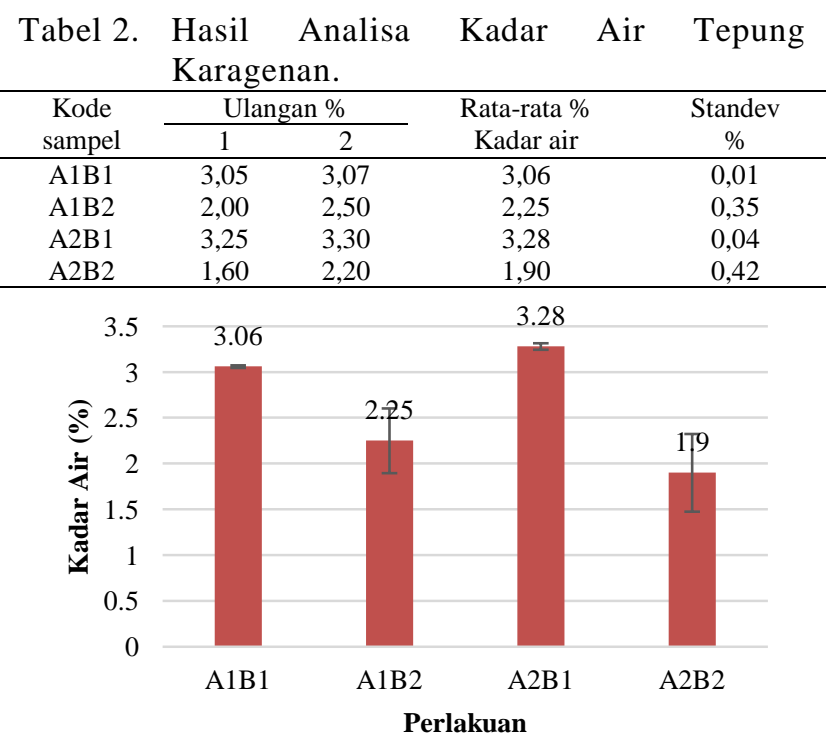

Gambar 2. Histogram Kadar Air Tepung Karagenan Rumput Laut Merah Kappaphycus alvarezii.

Ket. A1B1 ( NaOH 4\%, waktu ekstraksi 7 jam) A1B2 (NaOH 4\%, waktu ekstraksi10 jam) A2B1 (KOH 5\%, waktu ekstraksi 7 jam) A2B2 (KOH 5\%, waktu ekstraksi10 jam)

Hasil penelitian yang dilakukan oleh Panggabean et.al., (2018) menghasilkan kadar air untuk perlakuan $\mathrm{NaOH} 3 \%$ yaitu sebesar 
3,75 sedangkan untuk perlakuan $\mathrm{KOH} 4 \%$ sebesar 5\%. Sedangkan penelitian yang dilakukan oleh Erjanan (2017) menghasilkan kadar air tertinggi sebesar $22,37 \%$ pada konsentrasi $\mathrm{KOH} 0,01 \%$, sedangkan pada konsentrasi $\mathrm{KOH} \mathrm{0,15 \%} \mathrm{menghasilkan} \mathrm{kadar} \mathrm{air}$ sebesar $17,75 \%$. Berdasarkan hasil penelitian ini (Gambar 2) menunjukkan bahwa penambahan konsentrasi alkali dan waktu ekstraksi mempengaruhi kandungan air dalam tepung karaginan menjadi lebih rendah, hal ini diduga disebabkan oleh kemampuan larutan alkali dalam mengekstrak dan menghambat terjadinya peningkatan air dalam molekul rumput laut Kappaphycus alvarezii sehingga kadar air menjadi berkurang.

Kadar air karaginan yang dihasilkan dapat dipengaruhi oleh beberapa faktor, diantaranya adalah jenis dan umur rumput laut yang digunakan serta teknik ekstraksi yang dipakai dalam pembuatan karaginan. Penelitian yang dilakukan oleh Anwar et. al. (2013) bahwa penurunan kadar air alginate diakibatkan adanya suasana basa dari larutan $\mathrm{KOH}$ yang mampu menghambat terjadinya suatu peningkatan air dalam molekul alginat, dengan meningkatnya konsentrasi $\mathrm{KOH}$ yang digunakan maka dapat mengurangi garamgaram mineral yang terkandung di dalamnya. Selain itu, teknik pengeringan yang digunakan menjadi faktor utama yang mempengaruhi kadar air karaginan yang dihasilkan. Pengeringan hasil penelitian ini menggunakan alat kabinet drier dengan suhu oven berkisar antara $60-80^{\circ} \mathrm{C}$ dengan waktu pengeringan yaitu 3-4 jam.

\section{pH}

Dari hasil penelitian ini hasil uji nilai rataan stabilitas $\mathrm{pH}$ berkisar antara 6,79-8,91 dapat dilihat pada (Tabel3).

Karagenan akan stabil pada $\mathrm{pH} 7$ atau lebih, tetapi pada $\mathrm{pH}$ yang lebih rendah stabilitasnya akan menurun bila terjadi peningkatan suhu menurut Glicksman (1983). Kappa karagenan dan iota karaginan dapat digunakan sebagai pembentuk gel pada $\mathrm{pH}$ rendah tetapi kappa karagenan dan iota karaginan tidak mudah terhidrolisis sehingga tidak dapat digunakan dalam pengolahan pangan pada $\mathrm{pH}$ rendah $(3,0-4,0)$ (Moirano,1977). Hasil penelitian yang dilakukan (Panggabean 2018) stabilitas $\mathrm{pH}$ untuk sampel A (NaOH 3\%) adalah 8,06 dan sampel B (KOH 4\%) adalah 8,69 menunjukkan bahwa stabilitas $\mathrm{pH}$ yang diperoleh bermutu baik. Stabilitas $\mathrm{pH}$ pada penelitian ini (Gambar 3) menunjukkan bahwa stabilitas $\mathrm{pH}$ untuk perlakuan A2B2 ada pada $\mathrm{pH}$ asam. Hal ini disebabkan saat proses pemisahan filtrate ke endapan dimana perlakuan A2B2 mendapatkan perlakuan paling terakhir sehingga memicu terjadinya hidrolisis karbohidrat menjadi senyawa-senyawa yang lebih kompleks sehingga kandungan keasaman pada filtrates makin meningkat sedangkan pada perlakuan A1B1 mendapatkan hasil nilai $\mathrm{pH}$ yaitu sebesar 8,91 yang merupakan $\mathrm{pH}$ basa hal ini disebabkan oleh konsentrasi alkali $\mathrm{NaOH} 4 \%$ yang mempunyai sifat basa kuat sehingga mempengaruhi nilai $\mathrm{pH}$ menjadi basa. Jadi stabilitas $\mathrm{pH}$ penelitian ini mendapatkan hasil mutu karaginan yang telah memenuhi syarat karena batas pengolahan pangan mensyaratkan $\mathrm{pH}$ karaginan harus di atas 3,0-4,0 stabilitas $\mathrm{pH}$.

Tabel3. Hasil Uji Stabilitas pH pada Tepung Karagenan.

\begin{tabular}{|c|c|c|c|c|}
\hline \multirow{2}{*}{$\begin{array}{c}\text { Kode } \\
\text { sampel }\end{array}$} & \multicolumn{2}{|c|}{ Ulangan } & \multirow{2}{*}{$\begin{array}{c}\text { Rata-rata } \\
\mathrm{pH}\end{array}$} & \multirow{2}{*}{ Standev } \\
\hline & 1 & 2 & & \\
\hline A1B1 & 8,89 & 8,93 & 8,91 & 0,03 \\
\hline $\mathrm{A} 1 \mathrm{~B} 2$ & 7,55 & 7,60 & 7,58 & 0,04 \\
\hline $\mathrm{A} 2 \mathrm{~B} 1$ & 6,95 & 6,92 & 6,94 & 0,02 \\
\hline A2B 2 & 6,80 & 6,78 & 6,79 & 0,01 \\
\hline
\end{tabular}

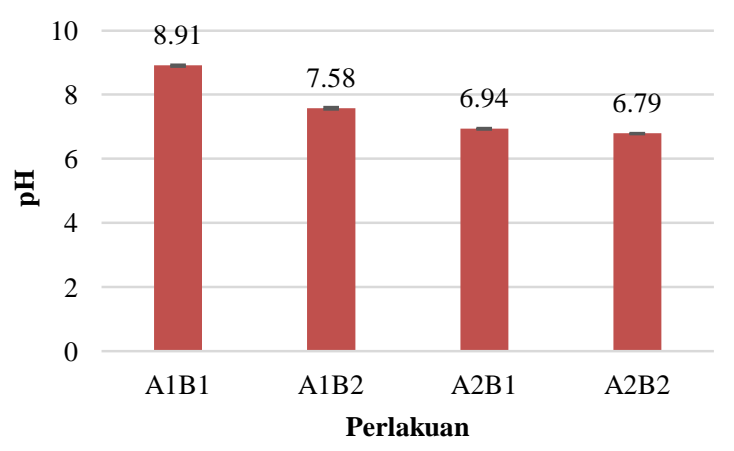

Gambar 3. Histogram pH Tepung Karagenan Rumput Laut Merah Kappaphycus alvarezii.

Ket. A1B1 (NaOH 4\%, waktu ekstraksi 7 jam) A1B2 ( NaOH 4\%, waktu ekstraksi10 jam) A2B1 (KOH 5\%, waktu ekstraksi 7 jam) A2B2 (KOH 5\%, waktu ekstraksi10 jam)

\section{Gel Strength}

Hasil analisa rataan kekuatan gel tepung karagenan yang diperoleh dari hasil penelitian ini berkisar antara 78,30-80,50 mm/g/det dapat dilihat pada (Gambar 4).

Menurut (Suwanto 2012) dalam bidang industri penetrometer digunakan untuk 
menentukan nilai kekenyalan atau kekerasan dari sejumlah bahan. Nilai kekerasan dan kekerasan ini disebut dengan konsistensi bahan. Semakin lunak/encer sampel, penekan penetrometer akan tenggelam makin dalam dan menunjukkan angka yang lebih besar.

Tabel 4. Hasil Uji Kekuatan Gel pada Tepung Karagenan.

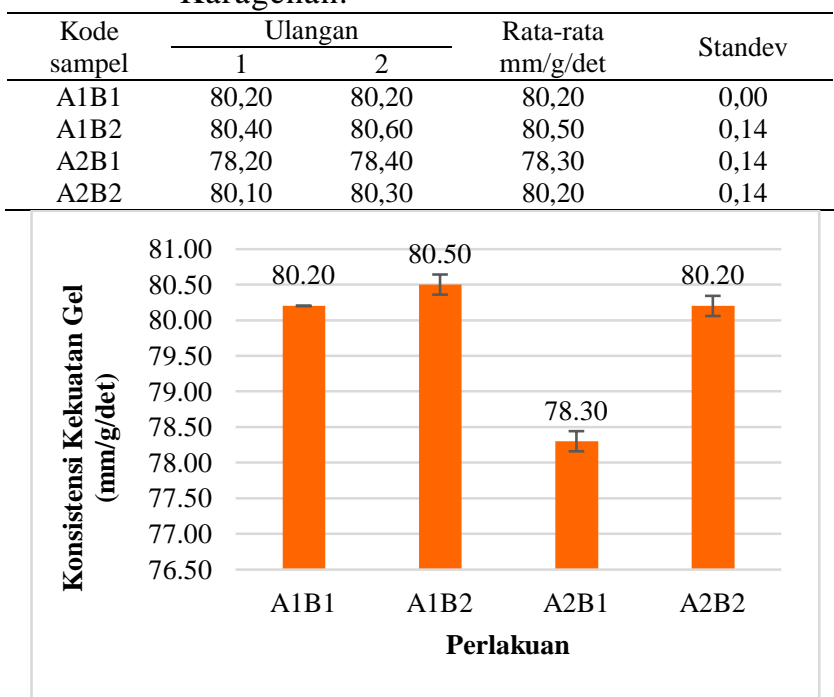

Gambar 4. Histogram Kekuatan Gel pada Tepung Karagenan Rumput Laut Merah Kappaphycus alvarezii.

Ket. A1B1 (NaOH 4\%, waktu ekstraksi 7 jam) A1B2 ( $\mathrm{NaOH} 4 \%$, waktu ekstraksi10 jam) A2B1 (KOH 5\%, waktu ekstraksi 7 jam)

A2B2 (KOH 5\%, waktu ekstraksi10 jam)

Analisis rataan kekuatan gel (Tabel 4) menunjukkan bahwa kekuatan gel terbaik ada pada perlakuan A2B1 (KOH 5\%, waktu ekstraksi 7 jam) yaitu $79,63 \mathrm{~mm} / \mathrm{g} /$ det dari total keseluruhan nilai konsistensi yaitu 370 $\mathrm{mm} / \mathrm{g} /$ det. Penetrometer yang digunakan dalam pengujian kekuatan gel ini adalah penetrometer buatan Jerman dengan satuan konsistensi $\mathrm{mm} / \mathrm{g} / \mathrm{det}$, dideskripsikan semakin kecil angka/nilai yang ditunjukkan maka tingkat kekenyalan kekuatan gel yang terkandung di dalam tepung karaginan semakin baik. Tingginya kekuatan gel karena kadar sulfat yang terkandung dalam tepung karaginan rendah. Dengan ditingkatkannya konsentrasi $\mathrm{KOH}$ dan $\mathrm{NaOH}$ dalam ekstraksi karaginan dapat meningkatkan kekenyalan gel sehingga angka konsistensi semakin kecil.

Sedangkan pada konsentrasi $\mathrm{KOH}$ meningkatnya kekuatan gel karena kemampuan alkali melepaskan sulfat pada C6 dan bersamaan dengan itu terjadi pembentukan 3,6anhidrogalaktosase hingga rantai polimer karaginan menjadi teratur dan mengakibatkan terjadinya peningkatan kemampuan struktur helix untuk membentuk gel (Alpis, 2002). Dapat disimpulkan kekuatan gel dari tepung karagenan yang diekstraksi dengan metode uap memiliki kemampuan dalam membentuk kekuatan gel yang sangat baik karena angka atau nilai konsistensi yang dihasilkan kecil.

\section{KESIMPULAN DAN SARAN}

\section{Kesimpulan}

Berdasarkan hasil data uji penelitian ekstraksi karaginan rumput laut merah Kappaphycus alvarezii dengan metode uap yang telah dilakukan, dapat diperoleh data rata-rata rendemen berkisar 13,62-18,15\%, kadar air 1,9-3,28\%, kadar abu 14,31-18,46\%, pH 6,798,91 , dan kekuatan gel 78,3-80,5 mm/g/det.

Perlakuan konsentrasi dan waktu ekstraksi memberikan pengaruh nyata terhadap proses pembuatan karaginan maupun hasil terhadap rendemen, kadar air, kadar abu, $\mathrm{pH}$ dan kekuatan gel.

Metode pembuatan karaginan ini dengan menggunakan metode uap telah terbukti menghasilkan karaginan murni dari rumput laut merah jenis Kappaphycus alvarezii dengan mutu karagenan yang telah memenuhi syarat FAO jika dilihat dari hasil yang diperoleh dari masing-masing analisis yang dilakukan, karena nilai rata-rata uji analisis berada dalam standar yang ditetapkan oleh FAO.

\section{Saran}

Perlu penelitian lanjutan untuk metode uap ini dalam mendapatkan hasil rendemen yang lebih banyak dan tingkat kesukaan atau organoleptik.

Perlu adanya modifikasi alat yaitu dengan ditambahkannya shaker pada wadah ekstraksi mesin uap.

\section{DAFTAR PUSTAKA}

Association of Official Analytical Chemists (AOAC). 2005. Official Methods of Analysis. Association of Official Analytical Chemists 18th ed. Chemist Inc. New York.

Alpis. (2002) Mempelajari Pembuatan Kloro Karagenan dari Rumput Laut Jenis Eucheuma cottonii dengan Penambahan Kombinasi Beberapa Konsentrasi KOH dan KCL (Skripsi). Bogor. Institut Pertanian Bogor.

Arfini, F. (2011) Optimasi Proses Ekstraksi Pembuatan Karaginan Dari Rumput Laut Merah (Eucheuma cottonii) Serta Aplikasinya Sebagai Penstabil Pada Sirup Markisa (Tesis). Bogor. Institut Pertanian Bogor. 
Atmadja, W., S. (2012). Apa Rumput Laut itu sebenarnya?. Diunduh pada tanggal 12 September 2018 dari http://www.coremap.or.id/print/article. php?id=264.

Atmadja WS., Kadi A. Sulistijo. Rachmaniar. 1995 Pengenalan Jenis-Jenis Rumput Laut Indonesia. Jakarta :Puslitbang Oseanologi-LIPI.

Atmadja WS, Kadi A, Sulistijo, Rahmaniar S. 1996. Pengenalan Jenis-Jenis Rumput Laut Indonesia. Jakarta :Puslitbang Oseanologi LIPI.

Anggadireja J.T. 1993. Potensi Makro Rumput Laut (Seaweed) sebagai Pangan dan Nilai Gizi Berbeda Jenis. Widya Karya Nasional Pangan dan Gizi V. LIPI. Jakarta 20-22 April 1993.

Anggadiredja JT. 2011. Laporan forum rumput laut. Pusat Riset Pengolahan Produk dan Sosial Ekonomi Kelautan dan Perikanan. Jakarta.

Bubnis WA. 2000. Carrageenan. http://www. fmcbiopolymer. com/ portals/bio/content/DOCS/ pharmaceuticals/problem\%20solver/section $\% 2013 \% 2$ 0c arrageenan.pdf. [8 September 2018].

Badan Pusat Statistik (BPS). (2015). Statistik Ekspor Impor Indonesia 2015

Bunga, S.M, Montolalu, R.I, Harikedua, Montalalu, L, Watung, H, dan Taher, N. 2013. Karakteristik Sifat Fisika Kimia Karaginan Rumput Laut Kappaphycus alvarezii Pada Berbagai Umur Panen yang Diambil dari Daerah Perairan Desa Arakan Kabupaten Minahasa Selatan.Jurnal Media Teknologi Hasil Perikanan. Vol. 1 No.2

Campo VL, Kawano DF, Silva DB, Ivone C. 2009. Carragenans: Biological properties, chemical modifications and structural analysis - A review. Carbohydrate Polymer 77: 167-180. http://www. elsevier.com/locate/carbpol [9 September 2018].

Ditjenkan Budidaya, 2004. Petunjuk Teknis Budidaya Laut: Rumput Laut Eucheuma Cottonni spp. Direktorat Jenderal Perikanan Budidaya. Departemen Kelautan dan Perikanan, Jakarta.

Distantina, S., Fadilah, Rochmadi, M. Fahrurrozi, dan Wiratni. 2010. Proses Ekstraksi Karaginan dari Eucheuma cottonii. Prosiding Seminar Rekayasa Kimia dan Proses. Hal : 21: 1-6.

Djohar, A. M., Timbowo, M., S., Mentang, F., (2018) Tingkat Kesukaan Panelis Terhadap Penyedap Rasa Alami Hasil Samping Perikanan dengan Edible Coating dari Karagenan. Universitas Sam Ratulangi. Jurnal Media Teknologi Hasil Perikanan. Vol, 6, No 2.

Dumondor, B., Makapedua, M., D., Taher, N., Dotulong, V., Mongi, L., E., Montolalu, I., R., (2019) Kualitas Semi-Refined Carrageenan Chips Rumput Laut Merah Kappaphycus alvarezii dengan Menggunakan Cabinet Dryer. Universitas Sam Ratulangi. Jurnal Media Teknologi Hasil Perikanan. Vol, 7 No. 1.

Edy, S., Ngangi, E., dan Mudeng, J. 2017. Analisis kelayakan lahan budidaya rumput laut (Ulva sp.) pada lokasi rencana pengembangan North Sulawesi Marine Education Center di Likupang Timur. Fakultas Perikanan dan Ilmu Kelautan. Universitas Sam Ratulangi. Manado.

Erjanan, S. Dotulong, V dan Montolalu, R. 2017. Mutu Karagianan dan Kekuatan Gel dari Rumput Laut
Merah Kappaphycus alvarezii. Universitas Sam Ratulangi. Jurnal Media Teknologi Hasil Perikanan. Vol. 5 No.2.

FAO.(2010). Cultured aquatic species information programme. Eucheuma spp. Cultured Aquatic Species Information Programme. FAO Fisheries and Aquaculture Department. Rome.

Fardiaz. D. 1989. Hidrokoloid. Laboratorium Kimia dan Biokimia Pangan. PAU Pangan dan Gizi. IPB. Bogor.

Glicksman. M. 1983. Food Hydrocolloids. CRS Press. Inc. Florida. Volume II: 74-83.

Guiseley. K.B.. N.F. Stanley dan Whitehouse. 1980. Carrageenan. McGraw Hill co. New York. Pp: 199

Herliany E. N. (2011). Aplikasi Kappa Karaginan Dari Rumput Laut Kappaphycus alvarezii Sebagai Edible Coating pada Udang Kupas Rebus (Tesis) Bogor. Institut Pertanian Bogor.

International Trade Center (ITC). (2015). Data Ekspor Impor Rumput Laut Dunia HS 121220, HS 121221, HS 121229, HS 130231, HS 130239 Periode 20102014.

Kementerian Perdagangan (Kemendag). (2013). Memo Kebijakan: Upaya Peningkatan Efektivitas Sistem Resi Gudang Rumput Laut di Daerah Tertinggal. Diundu pada tanggal 11 Agustus 2018 dari http://www.kemendag.go.id/files/pdf/2013/01/07/ memo-kebijakan-rumput-laut-id0-1357539890.pdf.

Kotler, P. (1997). Manajemen Pemasaran. Edisi millennium. Prentice Hall Indonesia, Jakarta.

Lantah L. Puji, Montolalu L., Reo A. (2017) Kandungan Fitokimia dan Aktivitas Antioksidan Ekstrak Metanol Rumput Laut Kappaphycus alvarezii. Universitas Sam Ratulangi. Jurnal Media Teknologi Hasil Perikanan. Vol,5 No. 3.

Minghou TT. 2010. Processing and extraction of phycocolloids. China: Institute of Oceanology, Academia Sinica Qingdao. http://www.fao.org/docrep/field/003/AB728E/AB728 E09. htm. [30 Agustus 2018].

Montolulu R.I, Tashiro Y, Matsukawa S. Ogawa H. 2008. Effects extraction parameters on gel properties of carrageenan from $K$. alvarezii (Rhodophyta). J Appl Phycol 20: 521-526.

Musa, S., Sanger, G., Dien, A., H., (2017) Komposisi Kimia, Senyawa Bioaktif dan Angka Lempeng Total Pada Rumput Laut Gracilla edulis. Universitas Sam Ratulangi. Jurnal Media Teknologi Hasil Perikanan. Vol, 5. No. 3.

Mc Hugh DJ. 2003. A Guide to The Seaweed Industry. FAO Fisheries Technical Paper. Rome: FAO.

Moirano, A. L, (1977). Sulfated Seaweed Polysaccharida: Food Colloids. M.D. Graham (ed). Avi Pub. Co. Connec.

Ningsih, F. L. 2014. Jenis dan Konsentrasi Alkali dengan Presipitasi $\mathrm{KCl}$ yang Berbeda Terhadap Mutu Karaginan dari Rumput Laut Kappaphycus alvarezii Asal Pulo Panjang Serang Banten. (Skripsi). Universitas Ageng Tirtayasa. Serang. $70 \mathrm{hlm}$.

Neish IC. 1989. Alkali treatment of carrageenan bearing seaweeds past, present and future. FMC Corporation, Marine Colloid Div. 11 hlm. 
Nurmiah S. (2013) Proses Prosuksi Skala Pilot Plant dari Rumput Laut Kappaphycus alvarezii dan Pemetaan Potensinya. (Skripsi) Bogor: Institut Pertanian Bogor.

Panggabean J. E, Dotulong, V, Montolalu I. R, Damongilala, L, Harikedua D. S, Makapedua, M. D. (2018) Ekstraksi Karaginan Rumput Laut Merah (Kappaphycus alvarezii) dengan Perlakuan Perendaman dalam Larutan Basa. Universitas Sam Ratulangi. Jurnal Media Teknologi Hasil Perikanan. Vol. 6, No. 3.

Patent EP0964876. 1998. Method for extracting semirefined carrageenan from seaweed.

Prasetyowati, Jasmine A. C, Agustiawan D. 2008. Pembuatan tepung karaginan dari rumput laut (Eucheuma cottonii) berdasarkan perbedaan metode pengendapan. Jurnal Teknik Kimia. 2 (15): 27-33.

Rahman FA. 2009. Perancangan klaster aqua bisnis rumput laut Eucheuma cottonii di Kabupaten Lombok Timur [tesis]. Malang: Universitas Brawijaya.

Rizal, M., Mappiratu, dan A. R. Razak. 2016. Optimalisasi Produksi Semi Refined Carrageenan (SRC) dari Rumput Laut (Eucheuma cottonii). Jurnal Kovalen. 2 (1): 33-38.

Rifansyah, A. 2016. Isolasi Dan Karakterisasi Karaginan Dari Alga Merah Eucheuma cottonii Dengan Metode Pengendapan Garam Alkali. Universitas Bandar Lampung. Skripsi.

Sahabati. S, Mudeng, J., Mondoringin, L. 2016. Pertumbuhan rumput laut (Kappaphycus alvarezii) yang dibudidaya dalam kantong jaring dengan berat awal berbeda di Teluk Talengen Kepulauan Sangihe. Universitas Sam Ratulangi.

Saputra, R., 2012, Pengaruh Konsentrasi Alkali dan Rasio Rumput Laut-Alkali Terhadap Viskositas dan Kekuatan Gel Semi Refined Carrageenan (SRC) dari Rumput Laut Eucheuma cottonii, Skripsi, Program
Studi Keteknikan Pertanian Universitas Hasanuddin, Makassar.

Sanger, G., Assa, R. Y., (2018) Pengembangan Produksi Minuman Rumput Laut E. Cottonii di Kelurahan Malalayang Dua Kecamatan Malalayang, Kota Manado. Universitas Sam Ratulangi. Jurnal Media Teknologi Hasil Perikanan. Vol. 6. No. 2.

Sanger, G., 2009. Mutu Permen Rumput Laut (Eucheuma cottonii). Fakultas Perikanan dan Ilmu Kelautan. Unsrat. Manado.

Stanley NF. 1987. Production, properties and uses of carrageenan. Di dalam: Mc Hugh DJ, editor. Production and Utilization of Products from Commercial Seaweeds. FAO Fish Tech Paper 288:116-146.

Suwanto P. E. (2012) Studi Perancangan Penetrometer Digital Sebagai Alat Uji Konsistensi Bahan Berbasis Mikrokontroler (Skripsi), Fakultas Matematika dan Ilmu Pengetahuan Alam. Institut Teknologi Sepuluh Nopember. Diakses 10 April 2019.

Tempo. (2013). Indonesia Hanya Bisa Budidaya Tiga Rumput Laut. Edisi 13 Oktober 2018.

Towle, A.G. 1973. Carrageenan. In : R.L. Whistler (Ed). Industrial Gum :Polysacharides and Their Derivates. Academic Press. London. Pp 84-109.

Wicaksono B. 1999. Formulasi gel pengharum ruangan dari karaginan [skripsi]. Bogor: Fakultas Perikanan dan Ilmu Kelautan IPB.

Winarno. FG. 1996. Teknologi Pengolahan Rumput Laut. Jakarta: Pustaka Sinar Harapan. Jakarta.

Winarno. FG. 1990. Teknologi Pengolahan Rumput Laut. Jakarta: Pustaka Sinar Harapan. Jakarta.

Yunizal. 2004. Teknologi Pengolahan Alginat. Jakarta (ID): Pusat Riset Pengolahan Produk dan Sosial Ekonomi Kelautan dan Perikanan. 